\title{
The possible negative consequences of underground dam and reservoir construction and operation in coastal karst areas: an example of the hydro-electric power plant (HEPP) Ombla near Dubrovnik (Croatia)
}

\author{
T. Roje-Bonacci and O. Bonacci \\ Faculty of Civil Engineering, Architecture and Geodesy, Split University, 21000 Split, Matice hrvatske 15, Croatia \\ Correspondence to: O. Bonacci (obonacci@gradst.hr)
}

Received: 5 April 2013 - Published in Nat. Hazards Earth Syst. Sci. Discuss.: 19 April 2013

Revised: 8 July 2013 - Accepted: 9 July 2013 - Published: 15 August 2013

\begin{abstract}
The Ombla Spring represents a typical abundant coastal karst spring located in the vicinity of the town of Dubrovnik (Croatia). Its outlet is at an altitude of $2.5 \mathrm{~m}$ above sea level ( $\mathrm{m}$ a.s.l.) and the water from it immediately flows into the Adriatic Sea. The minimum and maximum measured discharges are $3.96 \mathrm{~m}^{3} \mathrm{~s}^{-1}$ and $117 \mathrm{~m}^{3} \mathrm{~s}^{-1}$, respectively. The Trebišnjica River traverses through its catchment. The mean annual discharge, after the canalization of over $60 \mathrm{~km}$ of its watercourse with spray concrete (in the time span 1981-2011), is $24.05 \mathrm{~m}^{3} \mathrm{~s}^{-1}$. Before massive civil engineering work which took place during 1968-1980, the mean annual discharge was $28.35 \mathrm{~m}^{3} \mathrm{~s}^{-1}$. There is a project for construction of the hydro-electric power plant (HEPP) Ombla, which will exclusively use groundwater from the Ombla Spring karst aquifer. The underground dam will be constructed about $200 \mathrm{~m}$ behind the existing karst spring outflow in the karst massif, by injecting a grout curtain. The top of the grout curtain is planned to be at an altitude of $130 \mathrm{~m}$ a.s.l. This karst system is complex, sensitive, vulnerable and ecologically extremely valuable. The grout curtain, as well as the HEPP Ombla development, could lead to extremely dangerous technical and environmental consequences. In this paper some probable, negative consequences of the HEPP Ombla construction and development are explained. The HEPP Ombla could result in many large and hard-to-predict negative consequences which are specific for this particular HEPP, for example (1) severe spring discharge change; (2) unpredictable regional groundwater redistribution; (3) threatening of endemic fauna; (4) induced seismicity; (5) induced sinkholes; (6) occurrence of landslides;
\end{abstract}

(7) conflict regarding internationally shared karst aquifers; (8) intensification of karst flash floods; (9) sea water intrusion in coastal karst aquifer; etc.

\section{Introduction}

Natural as well as anthropogenic works in karst areas cause strong, sudden, hardly predictable and mostly dangerous processes with immeasurable consequences for the environment and social systems (e.g. Beck, 1984, 1989, 2005; Bonacci and Jelin, 1988; Drew and Hötzl, 1999; Breznik, 1998; Milanović, 2000, 2002; Beck and Herring, 2001; Bonacci, 2004; Waltham et al., 2005; Parise and Gunn, 2007; Bonacci et al., 2009 , etc.).

Karst is defined as a terrain, generally underlain by limestone or dolomite, in which the topography is chiefly formed by the dissolution of rock, and which is characterized by sinkholes, sinking streams, closed depressions, subterranean drainage and caves. A wide range of closed surface depressions, a well-developed underground drainage system, and strong interaction between the circulation of surface water and groundwater typify karst.

Diversity is considered the main feature of karstic systems, which are known to change very fast and in a hardly predictable manner over time and in space so that an investigation of each specific system is required. In karst terrains groundwater and surface water constitute a single dynamic system. The hydrocomplexity of karst regions is enormous. The determination of catchment boundaries and the 
catchment area is the starting point in all hydrologic analyses and one of the essential pieces of information which serve as the basis for all hydrologic calculations. In karst terrains this is always a very complex task (Gunn, 2007). Groundwater exchanges with adjacent aquifers through underground piracy routes or via inflows from surface streams. Consequently, only in exceptional cases do surface (topographic or orographic) and subsurface (hydrologic or hydrogeologic) catchment boundaries coincide. The problem is additionally complicated by the time-variant hydrologic boundaries which are dependent on fluctuations of groundwater levels (GWLs) (Bonacci, 1987, 2002; Kresic and Stevanovic, 2010).

Any kind of engineering action in a karst terrain presents numerous challenges to the engineer, including the unpredictable occurrence of cavities and well-developed hydraulic conduits which could lead to sinkhole development. The size and shape of a cavity in limestone depend on the interaction between the characteristics of geological structures, such as internal fractures or discontinuities, and water activity.

Human intervention, especially the construction of dams and reservoirs realized by creating large grout curtains (Bonacci et al., 2009), as well as interbasin water transfers through long tunnels and pipelines, can introduce instantaneous and distinct changes in catchment areas and boundaries, and, in turn, on the hydrological, hydrogeological and ecological regimes (limitation of energy flow, negative impacts on food cycle, blocking of convections between habitats and species, pollution of groundwater and underground environment, etc.) (Bonacci, 2004).

In recent times there have been many high disturbances often caused by human activities in karsts. North et al. (2009) gave interregional comparison of karst disturbance in westcentral Florida and southeast Italy, while van Beynen et al. (2012) discussed a sustainability index for karst environment. Both papers deal with indices for evaluating impacts and sustainability in karsts, and are therefore closely related to the issue dealt with here.

The project for construction of the hydro-electric power plant (HEPP) Ombla will exclusively use groundwater from the Ombla Spring karst aquifer. The underground dam will be constructed about $200 \mathrm{~m}$ behind the existing karst spring outflow in the karst massif, by injection of a grout curtain.

The main goal of this paper is to encourage further detailed interdisciplinary measurements and analyses in order to understand the possible negative consequences caused by the construction and development of the HEPP Ombla. The intention of the paper is to identify potential problems and to solve them before they occur in complex and poorly investigated karst environments. The HEPP Ombla system is internationally shared between Croatia and Bosnia and Herzegovina. Due to this reason one of the goals of the paper is to point out the specific characteristics of the karst aquifer and its water management, which can represent a real trigger for possible conflicts between the two neighbouring states.

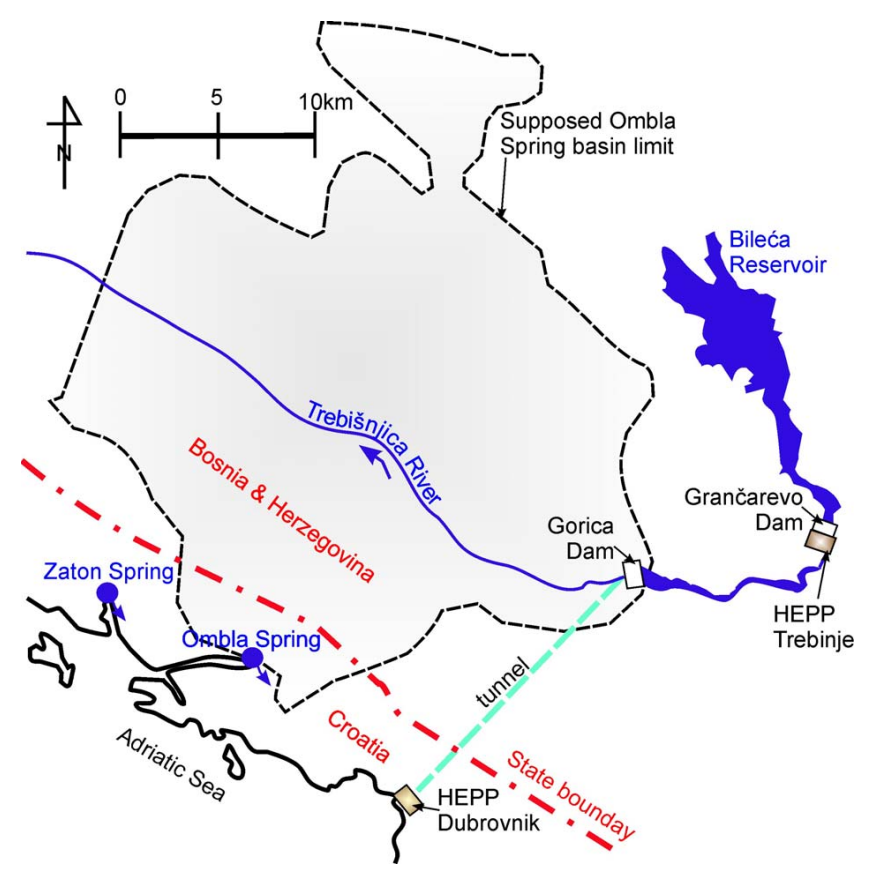

Fig. 1. Location map indicating the study area, the site of the Ombla Spring with its supposed catchment area, the Zaton Spring, the Trebišnjica River, the boundary limit between Croatia and Bosnia and Herzegovina, as well as the position of existing dams, reservoirs and HEPPs.

The HEPP Ombla example, apart from being an interesting case study, can be valuable for many other karst areas worldwide where engineering works and construction are taking place, especially those based on grout curtains. This paper focuses on the critical issues and priorities needed to address karst region risks and governance for disaster prevention.

\section{Short description of the natural characteristics of Ombla Spring and its catchment}

Figure 1 represents a map of the study area, the site of the Ombla Spring, with its supposed catchment area, the Zaton Spring, the Trebišnjica River, the boundary between Croatia and Bosnia and Herzegovina as well as the position of existing dams, reservoirs and HEPPs. The photograph presented in Fig. 2 shows the Ombla Spring from an areal view.

The catchment area and boundaries shown in Fig. 1 have been determined by using only geological data, without adequate hydrogeological data. The catchment area is estimated to be about $600 \mathrm{~km}^{2}$ (Milanović, 1996; Sever, 2003). According to the author's investigations which were based on water-budget analyses the catchment area is much larger, and ranges between $900 \mathrm{~km}^{2}$ and $1000 \mathrm{~km}^{2}$ (Žugaj and Bonacci, 1994). 


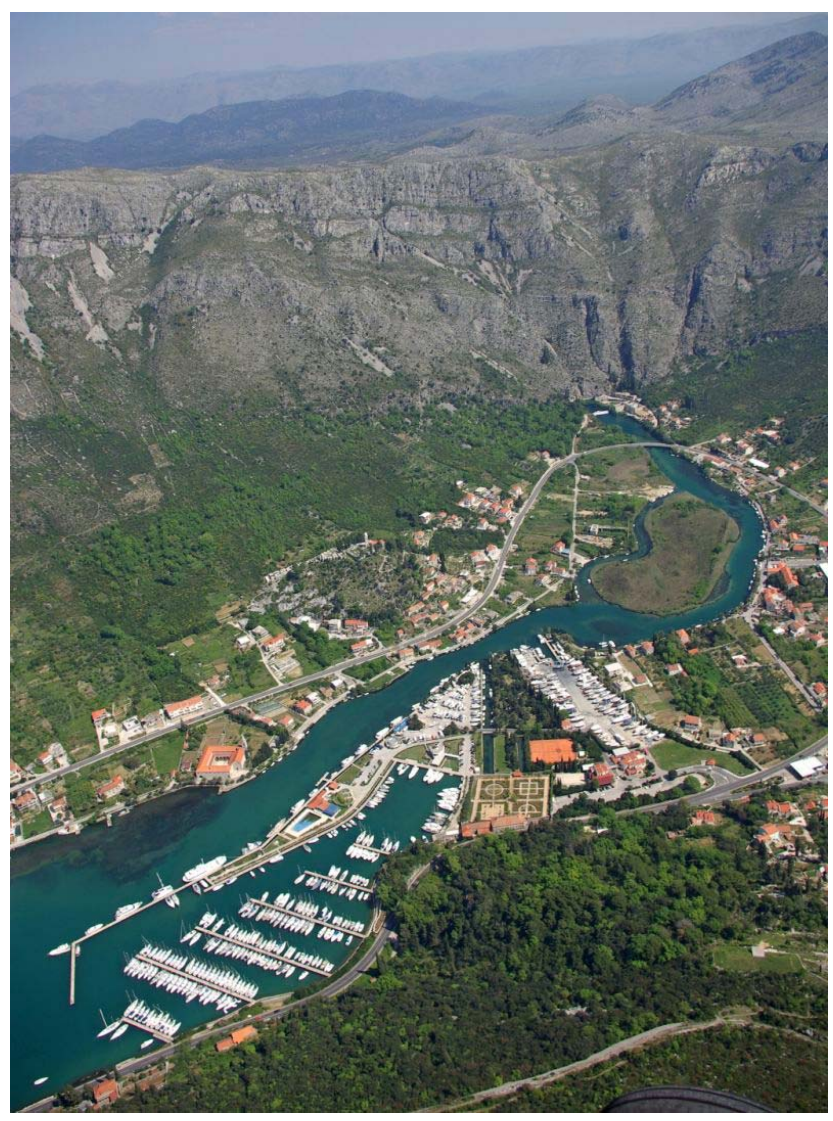

Fig. 2. Areal photograph of the Ombla Spring and surrounding area (taken by Antun Maškarić).

The geological setting is mostly composed of highly permeable Jurassic limestone, poorly permeable Triassic dolomite and Eocene flysch, which represent an impermeable hydrogeological barrier (Buljan et al., 2000; Sever, 2003; Paviša, 1998, 2003). The Quaternary sediments cover the bottom of the numerous poljes in the karst. They represent low-gradient features in the landscape. As a consequence of intense tectonic activity these poljes have been formed as terraces from an altitude of $1000 \mathrm{~m}$ a.s.l. to the sea level. From the hydrological and hydrogeological point of view, the poljes function as part of a wider system. They represent more-or-less interconnected subsystems within the process of surface and groundwater flow through the Ombla Spring karst catchment. The basic structural and stratigraphic units are elongated in a NW-SE direction, which follows the extension of the Dinarides.

About $90 \%$ of the whole Ombla Spring catchment is covered by limestone. Because of its high secondary and tertiary porosity, the water infiltration takes place very rapidly. The Trebišnjica River traverses the Ombla Spring catchment (see Fig. 1) and loses surface water through numerous sinks located along the bottom of this section, which is longer than $60 \mathrm{~km}$, thus recharging the Ombla Spring. In order to reduce losses, more than $60 \mathrm{~km}$ of the Trebišnjica River watercourse bottom have been covered with spray concrete. The maximum discharge capacity of this canal is about $50 \mathrm{~m}^{3} \mathrm{~s}^{-1}$. The average annual discharge of the Trebišnjica River in its natural state was about $68 \mathrm{~m}^{3} \mathrm{~s}^{-1}$. It should be noted that the river's natural regime has strongly changed due to the Bilece Reservoir operations and the HEPP Trebinje development.

The climate of the Ombla Spring outlet, measured at the Dubrovnik climatological station, is typically Mediterranean. In other parts of the catchment the climate changes as a function of the distance from the Adriatic Sea coast, moving from the Mediterranean to the continental and mountainous areas.

The average annual rainfall exceeds $1500 \mathrm{~mm}$, resulting from intensive convective precipitation of short duration through the entire year but particularly in October and November. About $70 \%$ of the total annual rainfall appears during the cold period of the year, from October to April. During thunderstorms intense precipitations of more than $10 \mathrm{~mm} \mathrm{~h}^{-1}$ occurs on average twice a year (Bonacci, 1995, 2004; Bonacci and Roje-Bonacci, 2000).

The average annual air temperature measured in Dubrovnik (1961-2012) is $16.5^{\circ} \mathrm{C}$. During the last two decades the annual average air temperature in Dubrovnik was $0.7^{\circ} \mathrm{C}$ higher than in the previous subperiod (19611990). This statistically significant trend of an increase in air temperature is found throughout the whole broader region. The average annual air temperature over the whole catchment is assessed to be about $13^{\circ} \mathrm{C}$.

The average annual water temperature measured at the outlet of the Ombla Spring (1962-2010) is $13.0^{\circ} \mathrm{C}$. In the case of water temperature no trend of increase or decrease has been found.

The minimum measured discharge of the Ombla Spring is $3.96 \mathrm{~m}^{3} \mathrm{~s}^{-1}$. Maximum measured discharges never exceeded a value of $117 \mathrm{~m}^{3} \mathrm{~s}^{-1}$, despite the fact that the spring catchment area is about $1000 \mathrm{~km}^{2}$, and precipitations are very intensive and abundant. The mean annual discharge after canalization of the Trebišnjica River watercourse with spray concrete is $24.05 \mathrm{~m}^{3} \mathrm{~s}^{-1}$. Before this massive civil engineering work, which took place during 1968-1980, the mean annual discharge was $28.35 \mathrm{~m}^{3} \mathrm{~s}^{-1}$. The Ombla Spring is a typical karst spring with a limited outflow capacity (Bonacci, 2001). Despite frequent and intense precipitation falling over its large catchment, the maximum possible discharge from the Ombla Spring is lower that $120 \mathrm{~m}^{3} \mathrm{~s}^{-1}$. The possible reasons for this limitation on its maximum flow rate can be the following: (1) limited size of the karst conduit; (2) pressure flow; (3) inter-catchment overflow; (4) overflow from the main spring-flow system to intermittent springs within the same catchment; and (5) water storage in the zone above the karst aquifer (Williams, 1983; Bonacci, 2001).

The GWL changes extremely rapidly (up to $100 \mathrm{~m}$ in $24 \mathrm{~h}$ ), and the total difference between the maximum and the minimum GWL in one piezometer can reach up to $200 \mathrm{~m}$ (Paviša, 1998, 2003). The maximum measured GWL rising intensity 
was $29.2 \mathrm{~m}$ per hour. The maximum measured GWL falling intensity does not exceed a value of $2 \mathrm{~m}$ per hour (Bonacci, 1995).

The regime of suspended sediment which outflows from the Ombla Spring outlet was measured from 2003 to 2010. The annual quantity of sediment varies between $88 \times 10^{3} \mathrm{tyr}^{-1}$ and $474 \times 10^{3} \mathrm{tyr}^{-1}$. Most of the sediment (more than $90 \%$ of whole annual amount) is delivered during the intensive short rainfall, in a few hours (Denić-Jukić et al., 2012).

\section{Underground dam and the HEPP Ombla}

In karsts, laminar and turbulent flow exist at the same time, and management and development of karst underground dams is very specific and different than in other, more homogeneous media. In the first part of this section some information about underground dams in karst regions will be given. In the second part, the main characteristic of the HEPP Ombla underground dam will be explained.

An underground dam is a facility that stores groundwater in the pores of strata. Recently, the concept of the underground dam has spread, and many have been constructed (Ishida et al., 2011). Only few of the recently built underground dams have been realized by using grout curtains. The grout curtain height typically ranging from 10 to $40 \mathrm{~m}$.

The most underground karst underground dams have been constructed in China. Carbonate rocks cover about $450000 \mathrm{~km}^{2}$ of the Chinese territory, mostly located in the southern tropical and subtropical region. All underground reservoirs are constructed by clogging large karst conduits and underground cave rivers. Their storage capacity is rather small; therefore water is practically only stored in the conduits and caves (Lin Hua, 1989).

During the 1990s, the Japan Green Resources Agency constructed subsurface dams in a limestone aquifer on Miyakojima Island located in Japan's subtropical climate zone. The project was completed in 2001. The dams are composed of a cut-off wall with a maximum height of $50 \mathrm{~m}$, by which the groundwater flow is dammed and the intrusion of sea water is prevented (Ishida et al., 2003, 2011). The cut-off walls were built using the in situ churning method. For irrigation purposes the groundwater is drown up by 147 tubes and stored in farm ponds (water tanks) until it is supplied through the pipeline systems that serve the entire island. In the Ryukyu limestone of Miyakojima Island, only small caves, several $\mathrm{cm}$ in diameter, exist.

Gilly and Mangin (1994) described field investigations made in order to create an underground reservoir in France by closing up the outlet of a small karst spring. This project has not been realized so far.

The HEPP Ombla underground dam will be constructed about $200 \mathrm{~m}$ behind the existing spring outflow in the karst massif (Fig. 3), by injecting a grout curtain. The projected

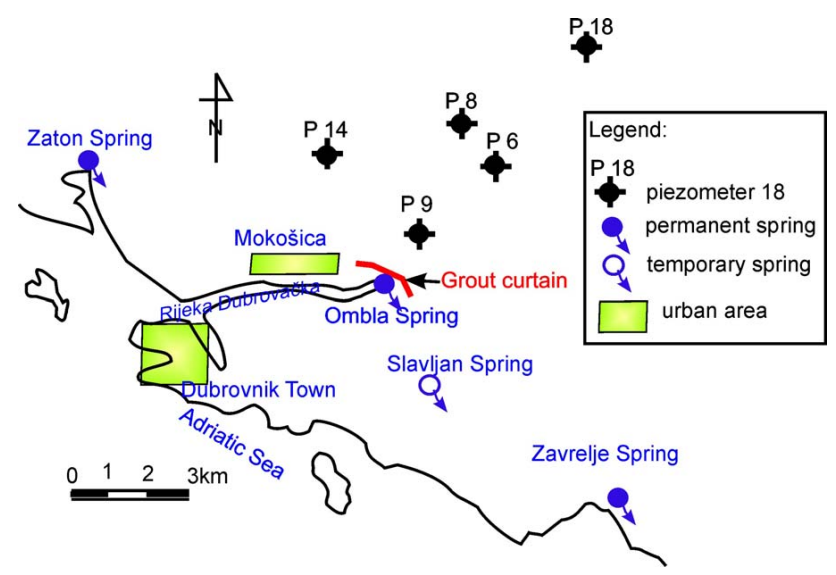

Fig. 3. Location map indicating the position of the projected grout curtain, five piezometers (P6, P8, P9, P14 and P18), the data of which are used in this article, and the adjacent karst springs (Zaton, Ombla, Slavljan and Zavrelje).

total area of the curtain is about $300000 \mathrm{~m}^{2}$. The total length of the curtain will be about $1470 \mathrm{~m}$, while its maximum depth will be $410 \mathrm{~m}$. Figure 4 shows a cross-section of the projected grout curtain (underground dam) (modified after Ravnik and Rajver, 1998; Sever, 2003). The top of the grout curtain is projected to be at an altitude of $130 \mathrm{~m}$ a.s.l. It is presumed that the grout curtain will be founded on an impervious flysch barrier. The grout curtain is planned to be constructed from three grouting galleries set up at different elevations (Fig. 4).

The installed discharge of the HEPP Ombla is $60 \mathrm{~m}^{3} \mathrm{~s}^{-1}$ (Sever, 2003). Four generating units will be located in the power house. Two of them will have Frances turbines with a rated discharge of $24 \mathrm{~m}^{3} \mathrm{~s}^{-1}$, and $30 \mathrm{MVA}$ synchronous generators. The other two generating units will have a rated discharge of $6 \mathrm{~m}^{3} \mathrm{~s}^{-1}$, and $8 \mathrm{MVA}$ synchronous generators. It has been assessed that the total HEPP Ombla rated power will be $68 \mathrm{MV}$, with a mean annual output of about $225 \mathrm{GWh}$. The bottom outlet has a multipurpose role. Besides functioning as the bottom outlet, it will be used as an emergency spillway and turbine discharge regulator as well as for water evacuation during and after the construction of the HEPP Ombla. Its maximum discharge capacity will be $113 \mathrm{~m}^{3} \mathrm{~s}^{-1}$.

\section{Possible negative consequences of the HEPP Ombla development}

Milanović (2002) has cited the following negative consequences of human activities and engineering construction in karst regions: (1) severe spring discharge change; (2) groundwater quality deterioration; (3) threatening of endemic fauna; (4) waste disposal failures; (5) induced seismicity; and (6) induced sinkholes. Bonacci (2004) has added the following hazardous consequences: (1) occurrence of landslides; (2) intensification of floods and droughts; (3) regional water 


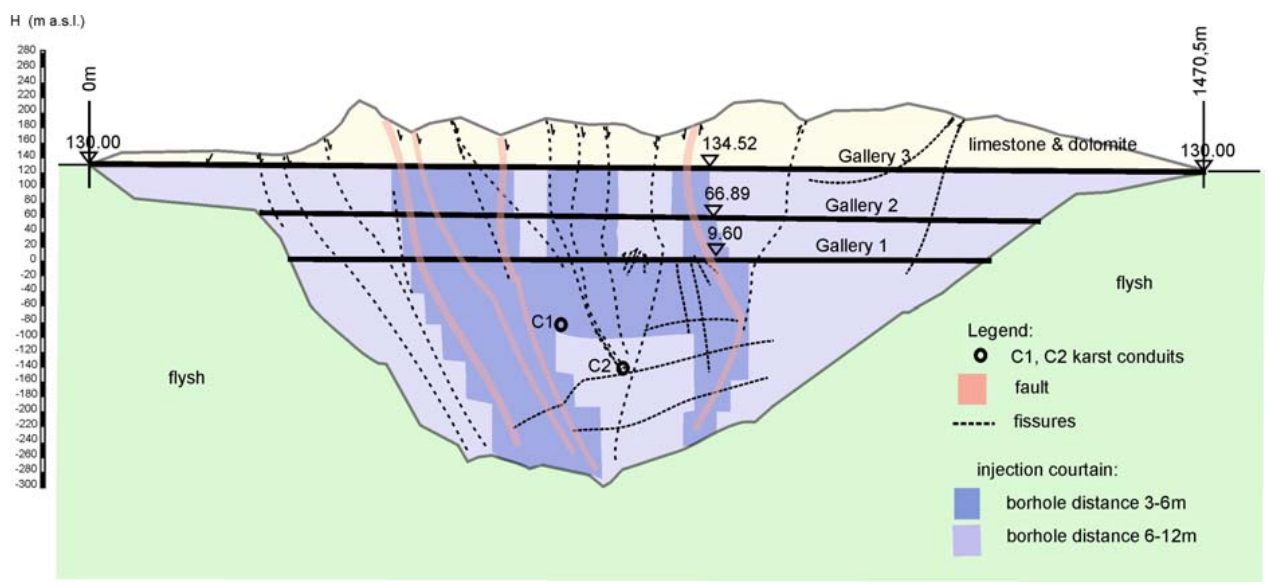

Fig. 4. Cross-section through the projected grout curtain (underground dam) (modified after Ravnik and Rajver, 1998; Sever, 2003).

redistribution; (4) conflict regarding internationally shared karst aquifers; (5) water losses from reservoirs (Bonacci and Rubinić, 2009; Bonacci and Roje-Bonacci, 2012); and (6) instability of dams built in karsts (Dreybrodt et al., 2002). As previously stressed, in karst terrains the relationship between surface water and groundwater is very closely connected and interrelated.

The construction and development of the HEPP Ombla can result in many large and hard-to-predict negative consequences. Some of them are specific for this particular HEPP.

It is not possible to determine the volume and extent of the underground reservoir, as well as its functioning. The crucial question, until now unsolved, is to what extent it will be possible to manage the water from a completely underground karst reservoir in which more than $95 \%$ of the groundwater is stored in small karst fissures and joints where diffuse laminar flow prevails (Bögli, 1980; Milanović, 1981; Bonacci, 1987; Ford and Williams, 2007). The natural behaviour of the karst aquifer through the Ombla Spring will be drastically changed by operation of the HEPP Ombla, but is not easy to predict in what manner.

\subsection{Changes in water regime}

The Ombla Spring mean annual discharges will be diminished because of increases in the GWL over the whole karst aquifer. It will cause more water overflow from the Ombla Spring catchment to other surrounding permanent and temporary karst spring catchments. Due to increasing of the GWL caused by grout curtain construction, some temporary karst springs in the local Ombla Spring catchment area could become permanent. In some cases these intermittent springs might remain intermittent, but their mean discharges could be higher. For the same reason, minimum spring discharges may be magnified. The maximum discharges may be magnified.

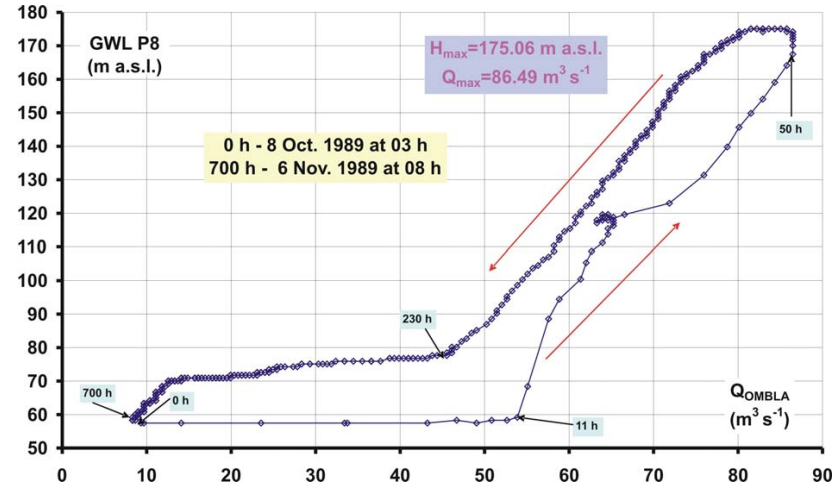

Fig. 5. Relationship between hourly Ombla Spring discharges and the GWL measured in piezometer P8 (modified according Bonacci, 1995).

Figure 5 represents the relationship between the hourly values of the GWL in piezometer P8 (Fig. 3), GWL P8, in $\mathrm{m}$ a.s.l., and the respective discharges of the Ombla Spring, $Q_{\text {OMBLA}}$, in $\mathrm{m}^{3} \mathrm{~s}^{-1}$ (Bonacci, 1995). It is of crucial importance to notice that the GWL stagnates in the period when the hydrograph increases from $9.32 \mathrm{~m}^{3} \mathrm{~s}^{-1}$ to $54.9 \mathrm{~m}^{3} \mathrm{~s}^{-1}$ (over $11 \mathrm{~h}$ ). The intensive rainfall which caused this hydrograph started $2 \mathrm{~h}$ earlier. This phenomenon can be explained by the fact that during $11 \mathrm{~h}$, large karst conduits were filled, and flow which was under pressure was formed only in the large karst conduits and caves where turbulent flow is present. At this time the small karst fissures in which diffuse laminar flow prevails were not filled by water (Bonacci, 1995). If this assumption is correct, it is possible to determine the volume of the large caverns to be about $1.5 \times 10^{6} \mathrm{~m}^{3}$. The relationship between GWL 88 and $Q_{\text {OMBLA }}$ differs during the rising and descending parts of the hydrograph. The formation of this loop can be explained by the different influence of turbulent and laminar flow. 


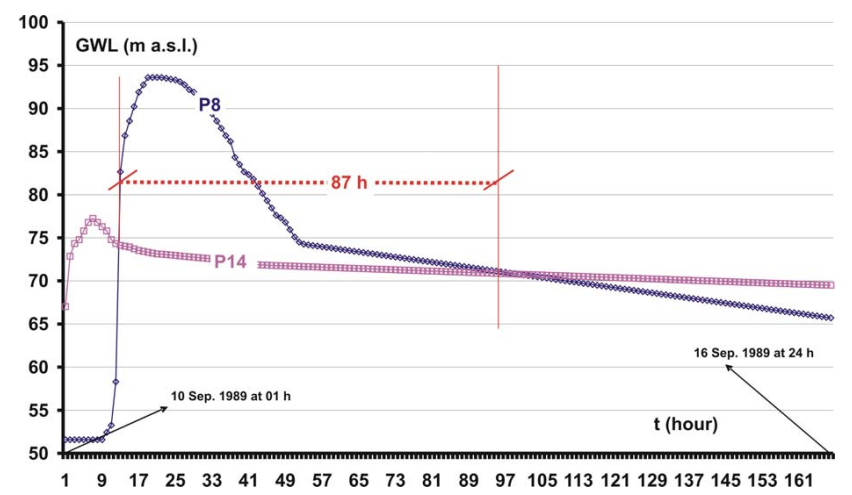

Fig. 6. Time data series of hourly GWL measured by piezometers P8 and P14 during high water caused by intensive precipitation.

Because of the much higher GWL caused by the grout curtain, increase in the number and duration of karst flash floods in the area of Mokošica (Fig. 3), a densely populated suburb of Dubrovnik, can be expected. High water, due to emptying of the underground reservoir, will cause higher flood levels, a likely cause of destruction. At the same time it is realistic to expect the occurrence of landslides along the Mokošica flysch slopes. The calculation of the Mokošica area slope stability had been performed with GWL at an altitude of $100 \mathrm{~m}$ a.s.l. The expectation of landslide occurrence is based on comparison with the Vajont landslide (Paronuzzi and Bolla, 2012), due to similarity of their geological settings. The Mokošica low permeable slope is built by Eocene flysch layers, which spread over the limestone and dolomite. The flysch layers can be influenced by high uplift caused by fast GWL rising. The siltstone layers in the flysch are very soft rocks, and sensitive to water content. In combination with low effective stresses and changes of its water content their shear resistance can be reduced.

It is very difficult to work out a reliable hydrologicalhydrogeological-hydraulic model of the functioning of the underground karst reservoir. In many cases, such as in the operation of the HEPP Ombla, this task is not possible because the exact boundaries of the catchment are not known. It is obvious that they change over time, being dependent on the fast and unknown changes of the GWL in this large, dynamic and inadequately investigated complex karst aquifer. The problem is that only a few active caves and conduits in the vicinity of the spring outflow are partly known. No other large underground karst space has been investigated well enough.

One good example of the fast and unexpected changes of the GWL in natural conditions in the Ombla Spring karst aquifer can be seen in the graph provided in Fig. 6, where two time data series of hourly GWL, measured by piezometers P8 and P14 (Fig. 3) during high water, are represented. At the same time, this representation can be used to explain the influences of the GWL changes on catchment boundary movement and the overflowing of groundwater from the Ombla

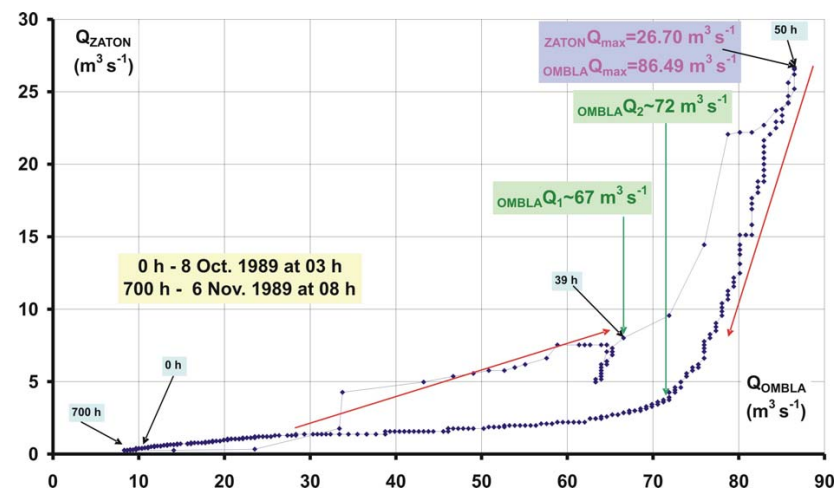

Fig. 7. Relationship between hourly discharges of the Ombla and Zaton springs (modified according Bonacci, 1995).

Spring to other neighbouring karst springs shown in Fig. 3. Two piezometers which are not very far from each other react very differently to the same precipitation. The GWL in P14 is generally higher than the GWL in P8. This means that during this period groundwater from P14 flows to the Ombla Spring aquifer. In the case when the GWL in P8 is higher than the GWL in P14, the overflow of groundwater from the Ombla Spring to the Zaton Spring (Figs. 1 and 3) appears. This overflow started when the GWL in both piezometers reached an altitude of $74 \mathrm{~m}$ a.s.l. and finished when both were at an altitude of $71 \mathrm{~m}$ a.s.l.

Figure 7 shows the relationship of the simultaneous hourly discharge of the Ombla and Zaton springs. It can be seen that the discharge of the Zaton Spring suddenly increased when that of the Ombla Spring exceeded values from $60 \mathrm{~m}^{3} \mathrm{~s}^{-1}$ to $70 \mathrm{~m}^{3} \mathrm{~s}^{-1}$. The Zaton Spring has a maximum capacity between $5 \mathrm{~m}^{3} \mathrm{~s}^{-1}$ and $6 \mathrm{~m}^{3} \mathrm{~s}^{-1}$ of the water discharging from its own catchment. Discharges above these values result from the overflow of water from the Ombla Spring catchment. It is necessary to notice the different behaviour in the relationship analysed in Fig. 7 during the rising and descending section of the GWL hydrograph. Bonacci (2004) showed that the overflow from the Ombla Spring catchment to the Zaton Spring catchment started when the GWLs at P9, P6 and P18 reached altitudes of $75 \mathrm{~m}$ a.s.1., $135 \mathrm{~m}$ a.s.1. and $165 \mathrm{~m}$ a.s.1., respectively. Piezometer P9 is only $1.4 \mathrm{~km}$ away from the projected grout curtain. This means that when the GWL in the underground reservoir will be higher than about $70 \mathrm{~m}$ a.s.1., overflow from the Ombla Spring catchment to the Zaton Spring catchment (and maybe in some other neighbouring karst springs) will occur.

\subsection{Influence of the grout curtain}

In this subsection, only the possible negative technical aspects of the grout curtain will be discussed. Grouting in karst terrains represents the injection of appropriate materials under pressure into rock through drilled holes to change 


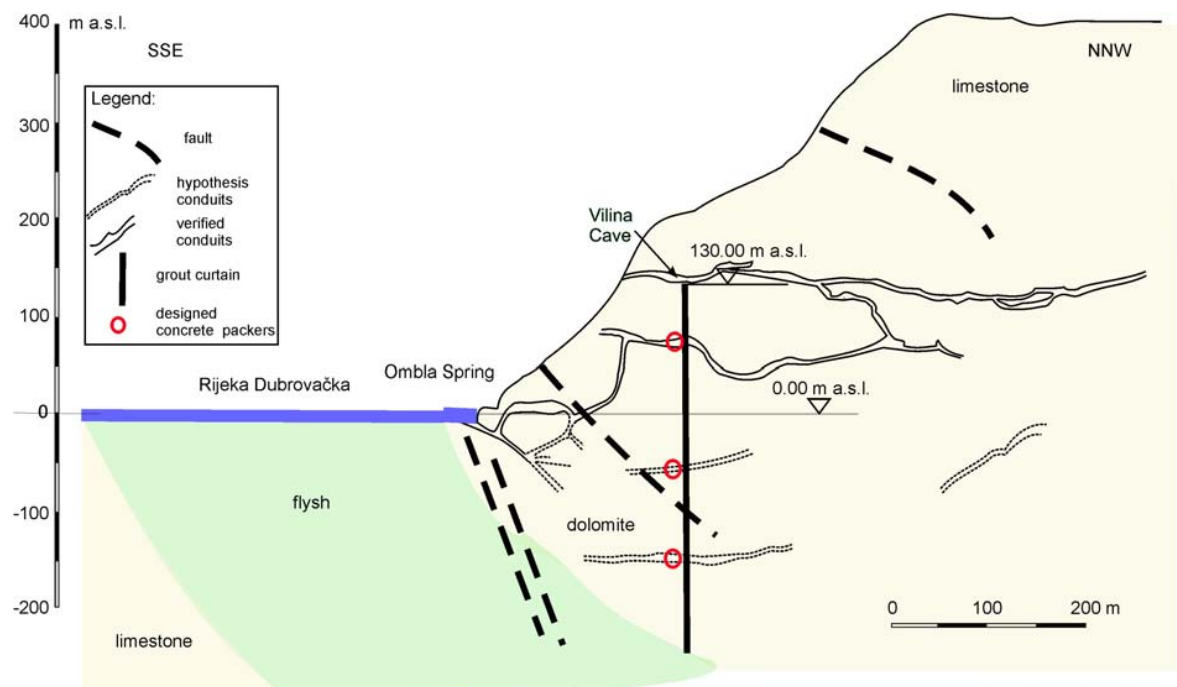

Fig. 8. Cross-section through the system of explored karst caves and large conduits in the vicinity of the Ombla Spring, indicating the location of some key parts of the projected HEPP Ombla, grout curtains and concrete blocks (modified after Ravnik and Rajver, 1998; Sever, 2003).

the physical characteristics of the karst formation. Its consequences should be the sealing of all kinds of karst voids in order to make the injected part of the karst massif less permeable and stronger. From the engineering point of view, grouting essentially consists of the waterproofing of a rock mass where there is a network of karst conduits, cracks, joints, fissures and excessive fragmentation (Nonveiller, 1989).

Injection pressure should not exceed the overburden stress because lifting on the horizontal planes could occur. In practice, the injection pressures used often exceed the maximum recommended values.

Figure 8 shows a cross-section through the system of explored karst caves and large conduits in the vicinity of the Ombla Spring, indicating the location of some key parts of the projected HEPP Ombla, the grout curtains and the concrete blocks (modified after Ravnik and Rajver, 1998; Sever, 2003). Attention should be drawn to the fact that three known large active karst conduits will be clogged by concrete packers. The designer is aware that it is not possible to plug such large karst cavities by injection. The main problem is that there might be additional active or large fossil cavities. Milanović (2002) pointed to the problem that high nonhomogeneity in the permeability of karsts makes it a most difficult target for grouting. Particular problems which can arise during grouting are zones of concentrated underground flow.

In the case of the grout curtain constructed at the Đale Reservoir (Cetina River in Dinaric karst of Croatia) Bonacci and Roje-Bonacci (2012) showed how quick and serious its impact was on the groundwater regime in karsts.

It is not possible to prevent water leakage from grout curtains, especially over long periods. This is especially important in the case of the HEPP Ombla grout curtain with its maximum height of $410 \mathrm{~m}$. When the grout curtain is finished the upgradient of the curtain is increased to levels which have never been previously realized. This increased pressure eventually results in "clay plugs" being expelled from some of the cavities adjacent to where the grout penetrates, opening up new cavities which might gradually enlarge as effective underflow conduits. The general conclusion is that the large hydraulic gradient imposed by the reservoir accelerates leakage. These high hydraulic gradients accelerate by orders of magnitudes through the dissolutional widening of fractures and bedding planes (Dreybrodt et al., 2002; Romanov et al.m 2003; Turkmen, 2003; Karimi et al., 2007; Rogers, 2007; Unal et al., 2007; Kaufmann and Romanov, 2008; Bonacci and Rubinić, 2009; Hiller et al., 2011; Bonacci and RojeBonacci, 2012; Zubac and Bošković, 2012).

Under the pressure of the underground reservoir head, internal erosion of the cavity infilling material creates piping. Water rinses filling of the karst features and widens openings, which results in an increasing volume of lost water, an increase in its velocity and higher erosive potential. Ultimately, this can result in the formation of collapse sinkholes. In Fig. 4, two large karst conduits are shown. Ravnik and Rajver (1998) discovered them by measuring groundwater temperatures in 30 deep piezometers drilled from an investigation gallery (gallery 1 in Fig. 4). These two karst conduits are active. Nobody knows how many fossil and inactive karst conduits there are in this space. Some of these could be reactivated due to the influence of high hydrostatic pressure which will be formed by the grout curtain. Regarding the functioning of the HEPP grout curtain Ravnik and Rajver (1998) have stressed that: "The positions and dimensions of all the basic structural elements of this power plant have now, after $20 \mathrm{yr}$ of interrupted investigations, been outlined. 
However, one very important problem remained unsolved, concerning the degree of impenetrability of the planned underground dam and especially of its lower part, which is located inside the rock massif below sea level."

As the Ombla Spring is a coastal karst spring there is a further likely problem. About $25000 \mathrm{yr}$ ago the Adriatic Sea level was $96.4 \mathrm{~m}$ lower than at present (Šegota, 1968), thus representing the karst base level. Due to this reason, there are many submarine springs along the Croatian Adriatic Sea coast. In the case of the currently active Ombla Spring, the possibility of inactive and blocked fossil conduits, which are expected to open under the influence of the new and much higher (than in its natural state) hydrostatic pressure caused by the grout curtain (underground dam) construction, cannot be excluded.

Regarding the operation of the HEPP Ombla grout curtain, it is of special importance to point to the case of the grout curtain of the Gorica Reservoir on the Trebišnjica River (see Fig. 1), which is constructed in the same catchment and geological setting as the HEPP Ombla, at a distance of about $20 \mathrm{~km}$. The loss of water from the Gorica Reservoir has a tendency toward constant growth, which creates a huge problem for water management in Trebišnjica's HEPP system. Zubac and Bošković (2012) propose building a new grout curtain, which should restore the existing degraded one which was built in 1981, only $33 \mathrm{yr}$ ago. This case indicates a probable fate of the HEPP Ombla grout curtain, which is at least five times higher.

The construction of the HEPP Ombla underground dam will definitely destroy the natural equilibrium between salt sea water and fresh water. The grout curtain will prevent fresh groundwater flow from the Ombla Spring aquifer to the downstream coastal area. Because of this, sea water will penetrate the local area downstream of the grout curtain. The consequences of this process should be investigated.

\subsection{Some other possible negative consequences and problems}

The questions are as follows: (1) what will be the spread of the underground reservoir under different GWL conditions? (2) What will be the maximum GWL altitudes in new conditions? Problems can be expected when intensive and abundant precipitation falls on the catchment, when the underground reservoir will be full. In this case the GWL can quickly rise more than $100 \mathrm{~m}$. It will cause not only the overflow of groundwater into neighbouring permanent and temporary karst spring catchments but also the overflow of groundwater downstream and upstream of the underground dam, where all the installation of the HEPP Ombla are planned. The rising of the GWL is a very rapid process which will not be possible to control efficiently by the HEPP Ombla operation (controlled releasing of water from the reservoir) as is possible in the case of a classic HEPP with surface reservoirs.

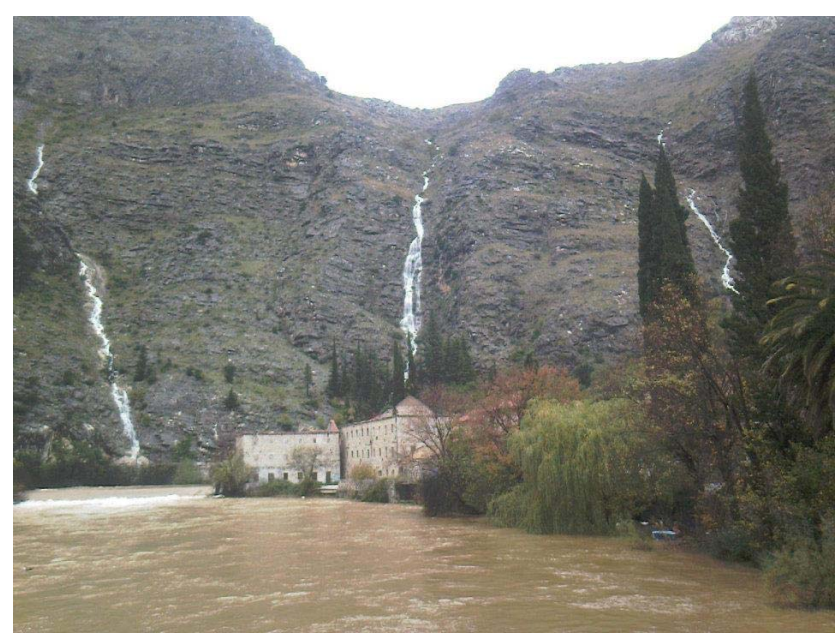

Fig. 9. Photograph of GWL overflow through three fossil karst conduits on 22 October 2010.

The photograph in Fig. 9 shows three torrential streams which formed on 22 November 2010 as a consequence of heavy intense rainfall. They outflowed from three fossil caves, where temporary karst springs were produced by a rapid rise in the GWL. These torrential streams, as well as many other smaller GWL breakthroughs from the karst massif in the broader area around the Ombla Spring, flooded the suburb of Dubrovnik Mokošica, causing serious damages.

At the same time it is realistic to expect the occurrence of landslides along the Mokošica steep and unstable flysch slopes, part of which are urbanized.

A higher-than-the-natural-state GWL caused by the grout curtain will diminish the vadose zone and increase the phreatic zone. The regime of suspended sediment will be definitely altered, but it is hard to assess to what extent. Most of the sediment will be separated through sedimentation in the karst matrix upstream of the grout curtain. The suspended sediment (mostly clay - terra rossa) will close the karst fractures, fissures and joints of the limestone and dolomite in the former vadose zone. Hydraulic conductivity in most of the karst matrix will decrease, capacity of the underground reservoir diminish and groundwater circulation change.

It is still a challenge to develop underground constructions in limestone areas, where the possibility of sinkholes and subsidence events always exists (Parise and Gunn, 2007). Identifying and predicting karst cavity networks which could cause sinkholes and subsidence on the ground surface would help engineers overcome this challenge (Waltham et al., 2005).

Dynamic interplay between sea water and flow discharging from the Ombla Spring in the Rijeka Dubrovačka has not been investigated sufficiently so far. It is known that during low discharges (until about $10 \mathrm{~m}^{3} \mathrm{~s}^{-1}$ ) fresh water flows over sea water without mixing. For higher discharges fresh spring water displaces sea water along different long sections of the 
Rijeka Dubrovačka (see Fig. 3). For greater discharges these sections are longer, but to what extent has not been yet investigated. It should be stressed that in the natural state, during high water, severe floods appear regularly once to twice yearly. The operation of the HEPP Ombla may aggravate this dangerous situation.

One of the greatest problems for conducting reliable analyses or modelling hydrological-hydrogeological processes in the analysed catchment is that the exact catchment boundary and area are not defined. The heterogeneity and anisotropy of the study area are extreme and not well understood. For this reason modelling the groundwater behaviour represents a great challenge. Modelling water circulation in the Ombla Spring catchment requires a mixture of surface water concepts and groundwater concepts. Karst hydrology and hydrogeology need all kinds of models and modelling, as well as the new scientific approaches, methods and technologies. At the same time one should be profoundly aware that they are only a useful tool but not a panacea. For complex karst systems, no single model can be all-embracing, so different models may be needed for different purposes, including explanation, prediction and control (Bonacci and RojeBonacci, 2012). This is especially true when prediction of the behaviour of a karst system due to HEPP development is attempted.

Jović (2003) made a numerical model of flows in the underground storage reservoir of the HEPP Ombla. The greatest and until now unsolved obstacles for flow modelling the vadose and phreatic zones of the large Ombla Spring underground karst massif are the geological setting and hydrogeological characteristics as well as the dimensions and positions of the main karst conduits. The local area around the Ombla Spring has until now been only partly investigated.

Bonacci $(1995,2000 \mathrm{~b})$ has shown how fast, unpredictably and over what a large range the values of hydraulic conductivity, K, change in time and space upstream of the Ombla Spring underground aquifer. This means that conditions for the reliable modelling of the functioning of this system are not fulfilled, and the real question is whether it is possible at all to fulfil such conditions in this large, deep and complex karst area. This is especially true in the case where modelling should take into account the anthropogenic influence of HEPP development on the regime of groundwater circulation. The previously explained phenomenon of the limited maximum discharge capacity of the Ombla Spring should be included in a rainfall-runoff model. Probably one of the reasons for the present poor quality of hydrological modelling in karsts is that this phenomenon has not been taken into consideration.

It is becoming increasingly critical for scientists and decision makers to become aware of the ways in which their work is influenced by legal and policy aspects. This is especially true for the case of the HEPP Ombla, which uses water from a transboundary karst aquifer divided by Croatia and Bosnia and Herzegovina. The large majority of this aquifer, as well as the Ombla Spring catchment, is in Bosnia and Herzegovina. The operation of the HEPP Ombla could cause trouble within the territory of Bosnia and Herzegovina, which could provoke international disputes. It can be expected that any problem in the part of the Ombla Spring catchment which belongs to Bosnia and Herzegovina will be explained as a consequence of the HEPP Ombla operation.

\subsection{Induced seismicity}

Large-scale fluid injections induce both seismic and aseismic motion (Cornet, 2012). The injection of fluid into a rock mass results in the variation of effective stresses that sometimes generate induced seismicity. An increase in pore pressure may induce some microseismic activity. RojeBonacci (1995) analysed the interdependence between the change in rock mass stress conditions caused by changes in piezometric pressures due to the impoundment of large reservoirs and induced seismicity observed in such structures. There are many studies of earthquakes triggered by artificial water reservoirs (e.g. Talwani and Acree, 1984; Stojić and Lalić, 1994; Gupta, 2002; Fan Xiao, 2012).

The oscillations of the GWL in the Ombla Spring aquifer are sudden and on a large scale. The changes they cause within the rock mass are so strong that they can lead to a redistribution of stress states and as such can cause sinkhole collapses (Roje-Bonacci, 1997).

Occurrences of a series of minor earthquakes and roars in the coastal karst Adriatic Sea area are quite frequent; those which occurred in the area of Dubrovnik were particularly intense (Cvijanović, 1971; Garašić and Cvijanović, 1991; Stojić and Lalić, 1994). The seasonal character leads to the assessment that they are caused by abundant precipitation and combined to presence of the large karst caves and conduits in the area. Garašić and Cvijanović (1986) maintain that earthquakes and speleological phenomena are related to the main fault zones and to the tectonic processes which have taken place.

Milanović (2002) believes that the abrupt rise of the GWL in the analysed Dinaric karst area compresses air trapped in karst conduits, caves and siphons. A trapped "air pillow" may thus escape, creating strong explosions felt by the inhabitants and recorded by the nearby seismological stations.

As concerns the HEPP Ombla, it is of crucial importance to take into consideration that induced seismicity has been triggered during the operation of large dams in the neighbouring Dinaric karst area of Grančarevo and Piva/Mratinje (Milanović, 2002).

Undoubtedly, the massive injections which should be done for the HEPP Ombla grout curtain construction will induce many small seismic motions followed by unpleasant acoustic effects. 


\section{Influence on the ecosystem}

The local area of the Ombla Spring is a nature park with protected flora and fauna, since this particular locality was recognized as an especially valuable and vulnerable coastal karst environment.

In regard to the ecological issues in karst terrains, Bonacci et al. (2009) stated: "The karst environment has very different characteristics than all other environments. The biological importance and particularities of karst are enormous. The evolution of entire karst landscapes is thought to be biologically controlled through the interrelationships of vegetative cover, erosion, and dissolution rates. Subterranean karst ecosystems are sensitive to environmental changes that occur on the surface. The importance of maintaining biological diversity goes far beyond mere protection of endangered species and beautiful landscape." This was also stated in the previously mentioned work by North et al. (2009), and was at the origin of the "biology" category in the karst disturbance index (KDI) evaluation.

Injection will definitely lead to many negative consequences for the underground ecosystem. The construction of the grout curtains will rashly, strongly and dangerously disrupt the existing vulnerable ecological equilibrium of the karst underground system. The natural food chain and the contact between species and their habitats will be lost in this very large but unknown underground space.

The main ingredients of a grout curtain (Portland cement, clay, bentonite, sand, asphalt and some chemicals) may be toxic, neurotoxic or carcinogenic, irritant to the skin or corrosive. Their use is dangerous for human beings and the environment. Such toxic components can pollute the karst aquifer and cause long-lasting hazardous consequences on karst underground species (Bonacci et al., 2009).

The penetration of salt sea water into the local area between the sea coast and the grout curtain will destroy the vulnerable ecological equilibrium.

In the valuable and vulnerable environment of the Ombla Spring, the hot spot is represented by Vilina Cave (see its position in Fig. 8). In this cave, seven sorts of bat have their habitats. The guano which they produce plays a crucial role for sustaining the life of all the other terrestrial as well as aquatic species in the Vilina Cave-Ombla Spring ecosystem. The construction of this extremely high grout curtain can have a strong and negative influence on the natural food chain in the Vilina Cave-Ombla Spring ecosystem, where eight cave species, five terrestrial and three aquatic (endemic and endangered), are found (Sket, 1997; Schütt, 2000; Bedek et al., 2006). The vadose zone will be decreased, and all terrestrial species which have habitats in this zone will be destroyed.

Despite the fact that the grout curtain will be constructed below the bottom of the Vilina Cave, the cave will be temporarily flooded. After heavy rainfall, a rapid and uncontrolled rise in GWL will occur. It is realistic to expect that the Vilina Cave will function as a temporary spring for the fast water evacuation from the karst aquifer to the surface. In this case all habitats and species from the Vilina Cave will be washed away and destroyed.

\section{Concluding remarks}

Problems discussed in this paper are extremely complex. In accordance with existing literature and authors' experience all (or at least most) of the risks previously discussed belong to the so-called "shallow uncertainties hazards", which arise when the probabilities of outcomes are reasonably well known. Deep uncertainties arise when the probabilities of outcomes are poorly known, unknown, or unknowable (Stein and Geller, 2012; Stein, 2013; Stein and Stein, 2013).

This is the first underground dam and reservoir of such size and height to be constructed in this deep, weakly investigated and extremely heterogeneous coastal area of Dinaric karst. The available data and information are not ample enough to make definite and reliable conclusions and offer technical solutions. On the basis of the analyses developed in this paper, it is very probable that the negative consequences of the construction and development of the HEPP Ombla will be very serious.

Generally speaking, each grout curtain acts individually. To understand its role and its influence on the environment, it is absolutely necessary to have long-lasting, continuous monitoring (before and after construction), at least for GWL, groundwater temperature, and the chemical composition of the water itself (Bonacci and Roje-Bonacci, 2012).

The present-day ecological and environmental aspects of grouting, i.e. its influence on this wonderful, valuable and vulnerable karst underground environment, has not drawn much attention, if any. This problem could be very serious, and due to this reason grouting in karsts should be treated with much great caution (Bonacci et al., 2009).

To obtain harmonious, reliable and sustainable development in this very complex, valuable and vulnerable ecological and social system, it is necessary to take the complex, interactive, technical, social, economic, environmental and cultural aspects of water resources management into account in decision making.

In the analysed case, issues of the transboundary karst water resources management represent an especially difficult and dubious task. Water policy is becoming progressively more relevant across different sectors (including energy, land use, natural resource management, health and the environment), and effective implementation is crucial for the sustainable development of all of these aspects.

The possibilities for overcoming karst system complexity can be found in close co-operation between hydrology and hydrogeology, as well as between different branches of the geosciences, and in implementation of detailed monitoring. The need for a better understanding of the deep and 
long-lasting mutual relationship between human activities and natural processes in karst terrains is of crucial importance. In order to achieve their real sustainable development, it is necessary to fill in the gaps which remain in the understanding of hydrological and ecological behaviour.

Edited by: M. Parise

Reviewed by: M. Petitta and T. Bechtel

\section{References}

Beck, B. F.: Sinkholes: Their geology, engineering and environmental impact, Proceedings of the first multidisciplinary conference on sinkholes, Orlando, 1984.

Beck, B. F.: Engineering and environmental impacts of sinkholes and karst, Proceedings of the third multidisciplinary conference on sinkholes, Orlando, 1989.

Beck, B. F.: Sinkholes and the engineering and environmental impacts of karst. Proceedings of the tenth multidisciplinary conference on sinkholes, San Antonio, 2005.

Beck, B. F. and Herring, J. G.: Geotechnical and environmental applications of karst geology and hydrology, Proceedings of the eighth multidisciplinary conference on sinkholes, Louisville, 2001.

Bedek, J., Gottstein-Matočec, S., Jalžić, B., Ozimec, R., and Štamol, V.: Katalog tipskih špiljskih lokaliteta faune Hrvatske (Catalogue of cave type localities of Croatian fauna), Natura Croatica, 15, 1-154, 2006.

Bögli, A.: Karst hydrology and physical speleology, Springer Verlag, Berlin, 1980.

Bonacci, O.: Karst hydrology with special reference to Dinaric karst, Springer Verlag, Berlin, 1987.

Bonacci, O.: Ground water behaviour in karst: example of the Ombla Spring (Croatia), J. Hydrol., 165, 113-134, 1995.

Bonacci, O.: Interpretation of groundwater level monitoring results in karts aquifers: examples from the Dinaric karst, Hydrol. Process., 14, 2423-2438, 2000a.

Bonacci, O.: Heterogeneity of hydrologic and hydrogeologic parameters in karst: example from Dinaric karst. Proceedings of the 6th international symposium and field seminar "Present state and future trends of karst studies", Marmaris, 393-399, $2000 \mathrm{~b}$.

Bonacci, O.: Analysis of the maximum discharge of karst springs, Hydrogeol. J., 9, 328-338, 2001.

Bonacci, O.: Development of catchment area in karst as a result of natural and anthropological factors, in: Evolution of karst: from prekarst to cessation, edited by: Gabrovšek, F., Inštitut za Raziskovanje Krasa, Postojna, 359-365, 2002.

Bonacci, O.: Hazards caused by natural and anthropogenic changes of catchment area in karst, Nat. Hazards Earth Syst. Sci., 4, 655661, doi:10.5194/nhess-4-655-2004, 2004.

Bonacci, O. and Jelin, J.: Identification of a karst hydrological system in the Dinaric karst (Yugoslavia), Hydrol. Sci. J., 33, 483497, 1988.

Bonacci, O. and Roje-Bonacci, T.: Interpretation of groundwater level monitoring results in karst aquifer: examples from the Dinaric karst, Hydrol. Process., 14, 2423-2438, 2000.

Bonacci, O. and Roje-Bonacci, T.: Impact of grout curtains on karst groundwater behaviour: an example from the Dinaric karst, Hy- drol. Process., 26, 2765-2772, 2012.

Bonacci, O. and Rubinić, J.: Water losses from a reservoir built in karst: the example of the Boljunčica reservoir (Istria, Croatia), Environ. Geol., 58, 339-345, 2009.

Bonacci, O., Gottstein, S., and Roje-Bonacci, T.: Negative impacts of grouting on the underground karst environment, Ecohydrol., 2, 492-502, 2009.

Bonacci, O., Pipan, T., and Culver, D. C.: A framework for karst ecohydrology, Environ. Geol., 56, 891-900, 2009.

Breznik, M.: Storage reservoirs and deep wells in karst regions, Balkema, Rotterdam, 1998.

Buljan, R., Prelogović, E., and Paviša, T.: Izvorište Ombla (The spring area of Ombla), Proceedings of 2nd Croatian geological congress, 555-560, 2000.

Cornet, F. H.: The relationship between seismic and aseismic motions induced by forced fluid injections, Hydrogeol. J., 20, 14631466, 2012.

Cvijanović, D.: Seizmičnost dubrovačkog područja (Dubrovnik region seismicity), Acta Seismologica Iugoslavia, 1, 31-56, 1971.

Denić-Jukić, V., Juras, T., Plenković, M., Kadić, A., and Jukić, D.: Turbidity dynamics of the karst spring Ombla (Croatia), Geophys. Res. Abstr., EGU2012-12428, EGU General Assembly 2012, Vienna, Austria, 2012.

Drew, D. and Hötzl, H.: Karst hydrogeology and human activities - impacts, consequences and implications, Balkema, Rotterdam, 1999.

Dreybrodt, W., Romanov, D., and Gabrovšek, F.: Karstification bellow dam sites: A model increasing leakage in reservoirs, Environ. Geol., 42, 518-524, 2002.

Fan Xiao: Did the Zipingpu Dam trigger China's 2008 earthquake? The scientific case, Probe International, 2012.

Ford, D. and Williams, P.: Karst hydrogeology and geomorphology, John Wiley, Chichester, 2007.

Garašić, M. and Cvijanović, D.: Speleological phenomena and seismic activity in Dinaric karst area in Yugoslavia, Proceedings of 9th international speleological congress, Barcelona, I, 94-97, 1986.

Garašić, M. and Cvijanović, D.: Seasonal occurrence of series of minor earthquakes and roars in the area of Dubrovnik, Ston and Mljet, Naš Krš, 30, 55-62, 1991.

Gilli, E. and Mangan, C.: Le prototype de Coaraze (AlpesMaritime), exemple de création d'une réserve d'eau souterraine par obturation d'une source karstique (The Coaraze prototype, an example of water underground storage by karstic spring closing (Alpes-Maritime, France), Karstologia, 24, 37-40, 1994.

Gunn, J.: Contributory area definition for groundwater source protection and hazard mitigation in carbonate aquifers, in: Natural and anthropogenic hazards in karst areas: recognition, analysis and mitigation, edited by: Parise, M. and Gunn, J., Geological Society of London, Special Publication, 279, 97-109, 2007.

Gupta, H. K.: A review of recent studies of triggered earthquakes by artificial water reservoirs with special emphasis on earthquakes in Koyna, India, Earth-Sci. Rev., 58, 279-310, 2002.

Hiller, T., Kaufmann, G., and Romanov, D.: Karstification beneath dam-sites: From conceptual models to realistic scenario, J. Hydrol., 398, 201-211, 2011.

Ishida, S., Kotoku, M., Abe, E., Faza, M. A., Tsuchihara, T., and Imaizumi, M.: Construction of subsurface dams and their impact on the environment, RMZ Material. Geoenviron., 50, 149-152, 
2003.

Ishida, S., Tsuchihara, T., Yoshimoto, S., and Imaizumi, M.: Sustainable use of groundwater with underground dams, Japan Agr. Res. Quarterly, 45, 51-61, 2011.

Jović, V.: Numerical model of flows in the underground storage reservoir of the Ombla HE plant - natural state and the state planned by the project, HYDRO 2003 conference proceedings, 1, 483-498, 2003.

Karimi, H., Keshavarz, T., Mohammadi, Z., and Raeisi, E.: Potential leakage at the Khersan 3 Dam Site, Iran: a hydrogeological approach, B. Eng. Geol. Environ., 66, 269-278, 2007.

Kaufmann, G. and Romanov, D.: Leakage of dam sites in karst terrains, Geophys. Res. Abstr., 10, EGU2008-A-02229, EGU General Assembly 2008, Vienna, Austria, 2008.

Kresic, N. and Stevanovic, Z.: Groundwater hydrology of springs, Elsevier, Amsterdam, 2010.

Lin Hua, S.: Subsurface reservoirs and karst geomorphology, Proceedings of the third multidisciplinary conference on sinkholes, Balkema, Rotterdam, 369-376, 1989.

Milanović, P.: Karst hydrogeology, Water Resources Publication, Littleton, 1981.

Milanović, P.: Ombla Spring, Croatia, Environ. Geol., 27, 105-107, 1996.

Milanović, P.: Geological engineering in karst, Zebra Pbl. Co., Beograd, 2000.

Milanović, P.: The environmental impacts of human activities and engineering constructions in karst regions, Episodes, 25, 13-21, 2002.

Nonveiller, E.: Grouting theory and practice, Elsevier, Amsterdam, 1989.

North, L. A., van Beynen P. E., and Parise, M.: Interregional comparison of karst disturbance: West-central Florida and southeast Italy, J. Environ. Manage., 90, 1770-1781, 2009.

Parise, M. and Gunn, J. (Eds.): Natural and anthropogenic hazards in karst areas: Recognition, Analysis and Mitigation, Geol. Soc. London, Special Publications, 279, 2007.

Paronuzzi, P. and Bolla, A.: The prehistoric Vajont rockslide: An updated geological mode, Geomorph., 169-170, 165-191, 2012.

Paviša, T.: Podzemna akumulacija u krškom terenu (Underground reservoir in karst terrain), Hrvatska Vodoprivreda, VII, 14-25, 1998.

Paviša, T.: HPP Ombla in Croatia - proposed use of energy from groundwater in karst aquifer, HYDRO 2003 conference proceedings, 1, 463-470, 2003.

Ravnik, D. and Rajver, D.: The use of inverse geotherms for determining underground water flow at the Ombla karst spring near Dubrovnik, Croatia, J. Appl. Geophys., 3, 177-190, 1998.

Rogers, D.: Hales Bar Dam and the pitfalls of constructing dams on karst foundation. Missouri University of Science \& Technology, available at: http:web.mst.edu/ rogerssda/dam/ (last access: 18 April 2013), 2007.

Roje-Bonacci, T.: Piezometarski pritisci, efektivna naprezanja, inducirani potresi (Piezometric pressures, effective stresses, induced seismicity), Proceeding of 1st Croatian water conference, Dubrovnik, 107-113, 1995.
Roje-Bonacci, T.: Influence of the fluctuation of groundwater levels upon the formation of sinkholes, in: Engineering geology and the environment, edited by: Marinos, P. G., Koukis, G. C., Tsiambaos, G. C., and Stournaras, G. C., Balkema, Rotterdam, 9971002, 1997.

Romanov, D., Gabrovšek, F., and Dreybrodt, W.: Dam sites in soluble rocks: a model of increasing leakage by dissolutional widening of fractures beneath a dam, Eng. Geol., 70, 17-35, 2003.

Schütt, H.: Die Hohenmollusken der Ombla-Quelle (The subterranean molluscs of the Ombla Spring), Natura Croatica, 9, 203215, 2000.

Šegota, T.: Morska razina u halocenu i mlađem würmu (Sea level in Halocen and Würm), Geografski Glasnik, 30, 15-39, 1968.

Sever, Z.: The Ombla HPP multipurpose project, HYDRO 2003 conference proceedings, 1, 455-462, 2003.

Shapiro, S. A., Rothert, E., Rath, V., and Rindschwentner, J.: Characterization of fluid transport properties of reservoirs using induced seismicity, Geophysics, 67, 212-220, 2002.

Sket, B.: Distribution of Proteus (Amphibia: Urodela: Proteidae) and its possible explanation, J. Biogeogr., 24, 263-280, 1997.

Stein, S.: Shallow versus deep uncertainties in natural hazard assessment, Eos Trans. AGU, 94, 133-134, 2013.

Stein, S. and Geller, R. J.: Communicating uncertainties in natural hazard forecasts. Eos Trans. AGU, 93, 361-362, 2012.

Stein, S. and Stein, J. L.: How good do natural hazard assessments needs to be?, GSA Today, 23, 60-61, 2013.

Stojić, P. and Lalić, R.: Potresi izazvani akumuliranom vodom (Earthquakes induced by reservoirs), Građevinski Fakultet, Split, 1994.

Talwani, P. and Acree, S.: Pore pressure diffusion and the mechanism of reservoir-induced seismicity, Pure Appl. Geophys., 122, 947-965, 1984.

Turkmen, S.: Treatment of the seepage problem at the Kalecik Dam (Turkey), Eng. Geol., 68, 159-169, 2003.

Unal, B., Eren, M., and Yalcin, M. G.: Investigating of leakage at Ataturk dam and hydro electric power plant by means of hydrometric measurements, Eng. Geol., 93, 45-63, 2007.

van Beynen P., Brinkmann R., and van Beynen K.: Karst a sustainability index for karst environments, J. Cave Karst Studies, 74, 221-234, 2012.

Waltham, T., Bell, F., and Culshaw, M.: Sinkholes and subsidence - Karst and cavernous rocks in engineering and constructions, Springer Verlag \& Praxis Publishing, Heidelberg \& Chichester, 2005.

Williams, P. V.: The role of subcutaneous zone in karst hydrology, J. Hydrol., 61, 45-67, 1983.

Zubac, Ž. and Bošković, Ž.: Problem vododrživosti akumulacije "Gorica"-Trebinje (Issue of losing waters from Gorica's reservoir), Vodoprivreda, 44, 273-276, 2012.

Žugaj, R. and Bonacci, O.: HE Ombla hidrološka obrada (HEPP Ombla hydrological analyses), Elektroprojekt Consulting Engineers, Zagreb, 1994. (unpublished). 